\title{
The US return to Asia does not close the window on China's strategic opportunity
}

\section{Mathieu Duchâtel}

Translator. N. Jayaram

\section{OpenEdition Journals}

\section{Electronic version}

URL: http://journals.openedition.org/chinaperspectives/5469

DOI: 10.4000/chinaperspectives.5469

ISSN: 1996-4617

\section{Publisher}

Centre d'étude français sur la Chine contemporaine

\section{Printed version}

Date of publication: 1 January 2011

Number of pages: $74-75$

ISSN: 2070-3449

\section{Electronic reference}

Mathieu Duchâtel, «The US return to Asia does not close the window on China's strategic opportunity », China Perspectives [Online], 2011/1 | 2011, Online since 30 March 2014, connection on 15 September 2020. URL : http://journals.openedition.org/chinaperspectives/5469 


\section{China Analvsìs \\ Les Nouvelles de Chine}

This section, prepared by the Asia Centre (www.centreasia.org), draws mainly on the press in Chinese, aiming to reflect the point of view of the People's Republic of China on international questions and issues related to Greater China.

\section{The US return to Asia does not close the window on China's strategic opportunity}

Analysis by Mathieu Duchâtel based on:

- Liu Jianfei, (1) "China's regional environment has not changed substantially," Liaowang dongfang zhoukan, 15 November 2010.

- "Interviews with Ma Xiaojun ${ }^{(2)}$ and Gao Zugui: ${ }^{(3)}$ A re-examination of China's strategic environment," Xuexi shibao, 10 January 2011.

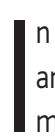
n late 2010 and early 2011, the Chinese press carried a number of analyses on the "deterioration of China's regional security environment." The expression counteracts the notion, disseminated mostly by American analysts, of assertiveness in China's foreign policy in the region. In Beijing experts' point of view, the list of negative developments is long, so much so that Ma Xiaojun even perceives a "new Cold War situation" (新的冷战格局, xin de lengzhan geju). In the South China Sea, parties contesting Chinese sovereignty over some islands have hardened their stance by moving closer to the United States. In China's maritime neighbourhood, the United States has held the biggest joint naval exercises with Japan and South Korea in the histories of the two respective alliances. In Japan, the Democratic Party quickly shed its accommodating China policy once it came to power. Chinese experts are in agreement that the main factor behind this deterioration is the "American return to East Asia" (重返东亚, chongfan dongya), symbolised by US participation in the East Asia Summit in October 2010 in Hanoi for the first time ever.

Liu Jianfei attributes the rise in regional tensions to a readjustment of the Obama administration's China policy. In November 2009, during the first US presidential trip to China, the Chinese side believed it had impressed on the Americans the need to respect its concepts - "mutual strategic confidence" and consideration for China's core interests. But Beijing quickly realised that Washington's so-called new China policy consisted of the same negative elements as during previous administrations: containment, encirclement, and balancing (牵制, 防范, 平衡, qianzhi, fangfan, pingheng), serving the strategy of safeguarding US supremacy in Asia and the world. In Liu's view, the US executive branch is under greater pressure now, as it has been weakened following the midterm Congressional elections and the global economic crisis. Consequently, Washington is seen as having overstepped the habitual limits of its hostile policies towards China by interfering in the South China Sea and openly backing Japan on the Senkaku/Diaoyu dispute. Gao Zugui's analysis differs in that he sees US reaction rather than hostile initiatives. This reaction is part of "offensive defence" (进攻性防御, jingongxing fangyu), a classic balancing response to rising Chinese regional influence.

From this, in Liu's view, insufficient "strategic communication" (战略沟通 不够, zhanluë goutong bu gou) amplified the discord between the two major powers by opening a space for perhaps exaggerated interpretations based on suspicions. Liu acknowledges that the Chinese perception of increased US interference in matters of Chinese security interests in East Asia had led Beijing towards a thorough revamping of its Asia strategy. The priority henceforth would be to "throw the Americans out of Asia" (将美国赶出东亚, jiang meiguo ganchu dongya). At the same time, Chinese diplomacy has ceased playing a responsible stakeholder (负责任的利益做关方, fuzeren de liyi youguanfang) role in major issues of global governance and regional security.

Nevertheless, Liu prefers to see the deterioration of China's security environment in relative terms. The focus is on problems in East Asia, because in other sub-regions of Asia, China enjoys rather stable relations with its neighbours. In reality, even in East Asian geopolitics, there has been a limited weakening (局部, jubu), far from global (全面, quanmian), of China's positions. As proof of this Liu cites the strengthening of the Sino-Russian partnership, a development overlooked by many observers, but which gave China elbow room in its dealings with Japan. Russian President Dmitry Medvedev's September 2010 visit ended with the signing of several cooperation accords and a joint communique marking the $65^{\text {th }}$ anniversary of the end of World War II. This text, with marked anti-fascist and anti-imperialist language, forged a Sino-Russian geopolitical front against Japan. In fact, a little after his China visit, Medvedev became the first Russian president to set foot on the Kuril Islands - occupied by Russia and claimed by Japan - striking a heavy blow (沉重的打击, chenzhong de daji) at Japan's far right and leading Beijing to adopt a hard line on the Diaoyu/Senkaku islands.

\footnotetext{
. Liu Jianfei is deputy director at the Institute of International Strategic Research at the Central Party School of the Chinese Communist Party.

2. Ma Xiaojun is a professor at the Institute of International Strategic Research at the Central Party School. 3. Gao Zugui is director of the Institute of World Politics at the China Institute of Contemporary International Relations.
} 
Further, in Liu's view, the US return to Asia does not signal a break with Washington's China policy by any means, and American disquiet over China's rise might need to be seen in context. US security priorities lie elsewhere, in Afghanistan and Iran, confronting Al-Qaeda and the spread of weapons of mass destruction. American geopolitical activism is focused on the Middle East crisis, and Washington is not seeking to fashion a new security order in East Asia. In this sense, the grand US strategy consists of preserving an upper hand in the international domain. Instead of countering the rising might of one country or another, it is more about refurbishing American domination over international affairs.

After all, no East Asian country that is cosying up to the United States has effected major changes to its China policy. The substantial cooperative ties between China and South Korea have survived the considerable deterioration to China's image among South Koreans following the Cheonan incident (in which 46 seamen died). Moves to set up an Asean +1 free trade zone have not been stalled by Southeast Asian countries despite tensions in the South China Sea. Even Japanese conservatives set store on mutually beneficial cooperation with China. On the whole, the foreign policy of each of China's neighbours in East Asia remains independent, far from being wholly subject to US interests. Rather, the countries seek to balance the benefits they gain from the two superpowers active in the region.

In this scenario, Liu arrives at a positive conclusion. Until 2020, Chinese foreign policy might continue riding on its "period of historic opportunity" (战略机遇期, zhanlue jiyuqi). Gao Zugui hardly differs, saying that it is enough for China to make no changes to its dual policy strategy of good neighbourliness and positive opening to Asian regionalism to continue gaining strength in East Asia. In his view, the series of incidents in 2010 in the Korean peninsula, around the Senkaku/Diaoyu islands, and in the South China Sea have rather underlined the shared responsibility of China and the United States in maintaining peace and stability in East Asia.

Iranslated by N. Jayaram 